\title{
Is Coming into Existence Always a Harm? Qoheleth in Dialogue with David Benatar
}

\author{
Jesse M. Peterson
}

Durham University; email: jesse.m.peterson@durham.ac.uk

\section{Abstract}

Contemporary philosopher David Benatar has advanced the self-evidently controversial claim that "coming into existence is always a harm." Benatar's argument turns on the basic asymmetry between pleasure and pain, an asymmetry he seeks to explain by the principle that those who never exist cannot be deprived. Benatar's import is almost incredible: humans should cease to procreate immediately, thereby engendering the extinction of the species - a view known as "anti-natalism." According to many of his readers, the ancient Hebrew sage Qoheleth expresses a pessimistic nihilism that runs as thick as Benatar's. Prima facie grounding for this assertion is that Qoheleth, like Benatar, raises the issue of whether coming into existence may be a harm - and gives an affirmative answer. In two passages, Eccl 6:1-6 and 4:1-3, Qoheleth declares that an unborn hypothetical person is "better off" than their existent counterpart. Yet the meaning and implication of these words is far from obvious. Does Qoheleth imply that the non-exister's state, and non-existence in general, is universally superior to existence? Or is he instead speaking exceptionally, of particular persons in rare circumstances? By examining the two "better"-statements in their literary context, I will argue that Qoheleth intends these examples as exceptions. He does not go so far as to make the supremely nihilistic claim that coming into existence is always, or even generally, a net harm; yet, he does concede that in certain cases, it can be. Beyond this, I will explore how the two thinkers' divergent conclusions can be traced to a deeper difference of philosophical method. This question concerning non-existence opens a window to Qoheleth's broader scheme of values and therefore serves as a surprisingly useful entry point by which to engage his philosophy. The paper utilizes 
the methodology Jaco Gericke has recently termed "philosophical criticism," but specifically applied to Qoheleth.

\section{Key Words:}

Ecclesiastes, Qoheleth, David Benatar, value of existence, Bible and philosophy

\section{Introduction: The Question of Qoheleth's Pessimism}

Albert Camus famously opined that "there is but one truly serious philosophical problem, and that is suicide." But one could argue that a question of even greater significance comes prior: not whether one should continue a life already being lived, but whether one should begin life in the first place. Contemporary philosopher David Benatar has recently advanced the self-evidently controversial claim that "coming into existence is always a serious harm." 2 This answer to the question of life's worth stands within the tradition of pessimism which stretches as far back as the Greek poet Theognis and the tragedians Sophocles and Euripides, ${ }^{3}$ was revived in the nineteenth-century writings of Schopenhauer, ${ }^{4}$ addressed by Nietzsche ${ }^{5}$ and is now represented within analytic philosophy most prominently by Benatar.

According to many of his readers, the ancient Hebrew sage Qoheleth fits squarely into this pessimistic stream, regarding life's value with a grim nihilism

\footnotetext{
${ }^{1}$ Albert Camus, The Myth of Sisyphus, and Other Essays (trans. Justin O'Brien; New York: Vintage, 1955) 3.

${ }^{2}$ David Benatar, Better Never to Have Been: The Harm of Coming into Existence (Oxford: Oxford University Press, 2006) 1. The term "harm" in this context refers to an overall "net harm" as opposed to a "net benefit" (1) as a value judgment concerning one's existence as a whole, in comparison to non-existence. See also Joel Feinberg, "Wrongful Life and the Counterfactual Element in Harming," Social Philosophy \& Policy 4 (1986) 145-78; Stephen Perry, "Harm, History, \& Counterfactuals," San Diego Law Review 40 (November 2003) 1283-313.

3 "It is best of all for mortals not to be born and not to look upon the rays of the piercing sun, but once born it is best to pass the gates of Hades as quickly as possible and to lie under a large heap of earth" (Theognis, 425-428 [Gerber, LCL]). "Not to be born is, beyond all estimation, best; but when a man has seen the light of day, this is next best by far, that with utmost speed he should go back from where he came" (Sophocles, Oed. Col. 1224-1226 [https://chs.harvard.edu/CHS/ article/display/5299]). "Not to be born is the same, I say, as to die, and to die is better than to live in pain" (Euripides, Tro. 636-639 [Kovacks, LCL]).

${ }^{4}$ Arthur Schopenhauer, The World as Will and Representation (trans. E. F. J. Payne; 2 vols.; New York: Dover, 1958) vol. 2; idem, Essays and Aphorisms (trans. R. J. Hollingdale; London: Penguin, 2004).

${ }^{5}$ In The Birth of Tragedy, Nietzsche recounts a legend derived from Aristotle's mostly lost Eudemos in which King Midas asks one Silenus "what is the best and most excellent thing for human beings." Silenus replies that "the very best thing is utterly beyond your reach: not to have been born, not to be, to be nothing" (Friedrich Nietzsche, The Birth of Tragedy and Other Writings [trans. Ronald Speirs; Cambridge: Cambridge University Press, 1999] 22-23 [italics in original]). Nietzsche cites this as part of his argument that "the Greeks knew the terrors and horrors of existence, but they covered them with a veil in order to be able to live" (124). This point of view, however, does not seem to have played a large part in Aristotle's philosophy.
} 
that runs as thick as Benatar's. ${ }^{6}$ Prima facie grounding for this assertion is that Qoheleth, like Benatar, raises the issue of whether coming into existence may be a harm-and gives an affirmative answer. In the two "better"-statements under discussion in this paper, Eccl 6:3 and 4:3, Qoheleth declares that a hypothetical non-existent person is better off than their existing counterpart. ${ }^{7}$ Yet the meaning and implication of the claim in both texts is far from obvious. Does Qoheleth imply that the non-exister's state is paradigmatically and universally superior? Or is he instead speaking exceptionally, of particular people in particular circumstances?

In this essay, I will begin by articulating the primary argument advanced by David Benatar for his "anti-natalism" philosophy. Secondly, by examining Qoheleth's two "better"-statements in their literary context, I will argue that he intends these examples as exceptions. He does not go so far as to make the supremely nihilistic claim that coming into existence is always, or even generally, a harm; yet he does concede that, in certain cases, it can be. Next, I will bring the two thinkers into dialogue, comparing certain aspects of Qoheleth's argumentation with Benatar's in order to discern why and where they part ways. Finally, I will conclude with a systematic schema for relating Qoheleth's values. ${ }^{8}$

${ }^{6}$ For example, Zimmermann's psychoanalytic construal of the sage remains one of the most pessimistic: "He is a pathological doubter of everything, stemming from a drastic emotional experience, a psychic disturbance. He is doubtful about himself as a person of worth and character. He has no self-esteem or value of himself. His doubt has destroyed all values. He is an inferior, of no account, and he demeans himself constantly. His doubt comes from a parapathy, a disease of the mind which he shares with many neurotics" (Frank Zimmermann, The Inner World of Qohelet [New York: Ktav, 1973] 8). With a more philosophical orientation, Seizo Sekine designates the sage as "Qoheleth the Nihilist"; see Seizo Sekine, Philosophical Interpretations of the Old Testament (BZAW 458; Berlin: De Gruyter, 2014) 123, and idem, "Qohelet als Nihilist," Annual of the Japanese Biblical Institute 17 (1991) 3-54.

${ }^{7}$ Statements to the effect that one is better off not to have been born may be found elsewhere in the ancient Jewish world, see Job 3:3-26; 10:18-19; Jer 20:14-18; 2 Esd 4:12; 5:35; 7:63, 116; 1 En. 38:2; 2 En. 41:2; Matt 26:24 (=Mark 14:21); b. 'Erub. 13b. Other ancient Near Eastern texts concern the question of life's value (usually on account of suffering) yet without framing it in explicitly anti-natalist terms, e.g., the Egyptian text Dialogue between a Man and his Ba; the Mesopotamian A Pessimistic Dialogue Between Master and Servant, Babylonian Theodicy, and Ludlul bēl nēmeqi; and the Sumerian Man and His God.

${ }^{8}$ I have chosen Benatar as a discussion partner with Qoheleth for a number of reasons. First, Benatar's brand of pessimism is stated not in terms of a simple disparaging of life's goodness or even a suicidal preference for death over life, but specifically in anti-natalist terms-never coming into existence in the first place is better than being born. This allows for a tight (but, as we will see, imperfect) parallel with Qoheleth's sentences in Eccl 4:3 and 6:3-and the parallel is strengthened by Qoheleth's penchant for specific "better-than" comparisons, exemplified in these two sentences. Second, Benatar is the first philosopher to use the rigorous logical methodology of analytic philosophy to make a case for anti-natalism - particularly in the "Asymmetry Argument" which I describe in this essay. This makes it harder to dismiss (than, say, E. M. Cioran's aphoristic pessimism in the mid-20 $0^{\text {th }}$ century), and it demands attention from serious philosophical thinkers to grapple with his claims. Third, presumably for the reason just given, Benatar has emerged as the most prominent philosophical pessimist writing today. His 2006 monograph has been the subject of numerous reviews and review essays, including an entire issue of the South African Journal of Philosophy devoted to it in 2012. I have chosen to compare these two particular thinkers rather than 
A broader aim of this paper is to utilize the methodology Jaco Gericke has recently termed "philosophical criticism," but specifically applied to Qoheleth. While recent decades of Qoheleth scholarship have witnessed some degree of philosophical thinking about Qoheleth-most notably with regard to his epistemology ${ }^{10}$ - the trend could benefit from additional scholarship in at least two respects: (a) the reference to philosophy has primarily been conducted from a traditional "biblical studies" perspective that may utilize some philosophical terms yet lacks the conceptual rigor of a deeper philosophical analysis of the texts; (b) several aspects of Qoheleth's philosophy have yet remained unexplored, and chief among these is Qoheleth's philosophy of value, arguably the most important lens through which to engage his worldview. My aim is to fill in what is lacking. By engaging Qoheleth in explicitly philosophical terms - in this case examining his views in relation to one contemporary philosopher of value - we may gain a more precise and systematic understanding of Qoheleth's underlying philosophy of life's value, which might otherwise remain opaque.

\section{David Benatar's "Anti-Natalism"}

David Benatar claims that "coming into existence is always a serious harm," or stated otherwise, that it is "better never to have been." a claim? Before stating Benatar's argument, we may consider a common intuitive conceptual framework for comparing the goods (pleasures) and harms (pains)

two broader traditions - e.g., that of ancient Near Eastern pessimism and that of Western philosophical nihilism - because this essay aims to uncover depth and texture at the cost of breadth and coverage.

${ }^{9}$ As advocated by Gericke (The Hebrew Bible and Philosophy of Religion [RBS 70; Atlanta: Society of Biblical Literature, 2012] 199-222), "philosophical criticism is understood as a descriptive type of philosophical analysis aimed at the clarification of meaning in the biblical texts" (201). Just as recent decades have witnessed the emergence of various biblical criticisms in which some strand of modern discourse is employed in order to illuminate an aspect of the ancient text (e.g., narrative criticism, performance criticism), so the same basic premise applies to "philosophical criticism." It is interested in "discovering what, if anything, a given passage assumes or implies on [philosophical] matters and in translating the findings of the analyses into philosophical terms," such that the ancient writer's implicit philosophy can be "identified, reconstructed, and elucidated" (201). The "translation" thus involved, from ancient thought categories to modern philosophical ones, must beware the danger of anachronism. On the other hand, as Gericke observes, "bracketing philosophical concerns actually makes one more (not less) prone to anachronistic philosophical eisegesis" (97).

Gericke's project, thus defined, differs from that of Yoram Hazony (The Philosophy of Hebrew Scripture [Cambridge: Cambridge University Press, 2012]). Hazony seeks to identify the biblical books as "works of philosophy" themselves, but Gericke only aims to read philosophically relevant portions of the text through the (ideally) clarifying lens of philosophical discourse.

${ }^{10}$ See, e.g., Michael Fox, “Qohelet's Epistemology,” HUCA 58 (1987) 137-55; Ryan P. O’Dowd, "Epistemology in Ecclesiastes: Remembering What it Means to Be Human," in The Words of the Wise are Like Goads: Engaging Qohelet in the 21 st Century (ed. Mark J. Boda et al.; Winona Lake, IN: Eisenbrauns, 2013) 195-217.

${ }^{11}$ Benatar, Better, 1. 
of coming into existence versus those of remaining non-existent. ${ }^{12}$ Under such a framework, it is the actual experiences of existing people, both pains and pleasures, that are compared with the hypothetical state of non-existence. Non-existence is, of course, characterized by absences (the absence of both pleasure and pain), while existence is marked by presences (the presence of both pleasure and pain). The absence of both pleasure and pain in non-existence would seem to render the overall value of this state as a "zero" (if put into quantitative terms) - neither positive nor negative, but value-neutral. If so, the question would then be whether the overall value of existence, with its presence of both pleasure and pain, will be greater or less than zero. A case against existence would presumably claim that life's pains outweigh its pleasures, rendering the net sum a loss.

But that is not Benatar's argument. ${ }^{13}$ Instead, Benatar's primary argument is an a priori argument, proceeding from definitional analysis rather than experiences. It analyzes the relative value of existence in comparison to non-existence by considering the way pleasure and pain inhere in either state as such (according to an assumed definition of that state), but this is done almost entirely apart from any consideration of the relative amounts of pleasure and pain actually experienced by existing persons. ${ }^{14}$ To make this case - which he elsewhere calls the "Asymmetry Argument"15 - Benatar refers to a basic asymmetry between pleasure and pain. Benatar claims that when we consider bringing future humans into the world, the avoidance of pain is almost always prioritized above the possibility of experiencing pleasure. Thus, for instance, we feel an obligation not to bring into the world a child who would be subjected to a life of utter misery, yet we sense no corresponding obligation to bring into the world a child who would live a happy life. The impulse underlying such a decision - this purportedly common asymmetry of values - is what Benatar wants to press to its logical conclusion. ${ }^{16}$

12 "Intuitive" in a way I hope to explain - though I acknowledge that casting the issue in terms of a distinction between "pleasures" and "pains" already frames the discussion within a rather utilitarian structure. I have done so simply because this is Benatar's starting point, but one burden of the paper is to test whether this sort of framework serves to illuminate Qoheleth's thought.

${ }^{13}$ At least, this is not his primary argument. He does, in fact, posit a separate argument appealing to human experience in his book's third chapter (Benatar, Better, 60-93), but he maintains that the argument described herein can independently justify his thesis (see Better, 18-59, for the full argument). In addition to considerations of space, I have chosen to focus on Benatar's Asymmetry Argument because its method of comparing the harms and benefits of existence with those of nonexistence runs so congruently with Qoheleth's approach.

${ }^{14}$ See Bruce Russell, “A Priori Justification and Knowledge," Stanford Encyclopedia of Philosophy (ed. Edward N. Zalta; Summer 2014) https://plato.stanford.edu/archives/sum2014/entries/apriori/.

15 David Benatar and David Wasserman, Debating Procreation: Is It Wrong to Reproduce? (Oxford: Oxford University Press, 2015) 19-39.

16 The reference to the values that "we" typically "feel" (in his view) does not undermine the point that Benatar's argument is an a priori one, since he is only drawing on these purportedly common asymmetrical value judgments as a pointer to an underlying fact about the world which he then justifies on a priori grounds and not because of any generally assigned asymmetrical values or any experiences of pain or pleasure in the world. 
Why do we value the avoidance of pain above the experience of pleasure? Benatar seeks to explain this basic asymmetry of values by evoking the principle that "those who never exist cannot be deprived" feel a lack - of goods or pleasures they have missed by not partaking of existence. ${ }^{18}$ Benatar takes this lack of felt deprivation to imply that the non-exister's pleasureless state is "not bad," even though this state is devoid of life's goods. ${ }^{19}$ Thus, however good life's pleasures may be for those who experience them, "the pleasures of the existent . . . are not an advantage over non-existence, because the absence of pleasures is not bad." ${ }^{20}$ The couple considering bringing into the world a would-be suffering child, then, will do no harm to the potential child by denying it existence, since the child would never know the difference, whereas they would harm the child by bringing it into the world, given life's inevitable pains. Benatar is claiming that the intuitive advantage we generally assume existence holds over non-existence by virtue of life's blessings should not be regarded as an "advantage" to those (nonexisters) who feel no lack or deprivation toward it. Yet this does not mean the playing field is even: non-existers, for their part, can benefit from their non-existent status by necessarily avoiding life's would-be pains. ${ }^{21}$ Given that life will always involve at least some pain, and non-existence will always retain its pain-free status, the net

${ }^{17}$ Benatar, Better, 1 [italics added].

${ }^{18}$ This paper will assume that it is meaningful and not senseless to speak of hypothetical or potential non-existent persons. Who are they? Essentially, they are those who could (or could have) come into existence if certain conditions were met, such as a particular pair of humans procreating at a certain time (see Mary Anne Warren, "Do Potential People Have Moral Rights?" Canadian Journal of Philosophy 7 [1977] 275-89). But a possible person might or might not be actualized; Benatar clarifies that he is "using 'non-existence' to denote those who never exist" (Better, 30 n. 22 [italics added]). The sense in which we may compare the state of such hypothetical people as better or worse than their corresponding hypothetically existent counterparts is only the sense in which we regularly compare possible situations to actual ones and inquire which is better.

19 This essential aspect of Benatar's argument was predated nearly two millennia by Lucretius: "How could it have harmed us never to have been created? Are we to believe that our life lay groveling in murk and misery until the first day of creation dawned for us? All people, once born, must certainly wish to remain in life, so long as seductive pleasure detains them; but if one has never tasted the love of life or been numbered among the living, how does it harm one not to have been created?" (Lucr. 5.173-181).

${ }^{20}$ Benatar, Better, 41 [italics added]. He adds, "For the good to be an advantage over non-existence, it would have to have been the case that its absence were bad" (ibid.). If we were to make explicit Benatar's implied premise we might syllogize as follows:

Premise A: $\quad$ If $\mathrm{X}$ is not bad, then nothing can be an advantage with respect to $\mathrm{X}$.

Premise B: $\quad$ The absence of pleasures (in non-existence) is not bad.

Conclusion C: The pleasures of the existent are not an advantage over (the absence of pleasures in) non-existence.

Once rendered in this way, Premise A strikes one as patently contestable, yet Benatar nowhere argues for it.

21 "There is a crucial difference between harms (such as pains) and benefits (such as pleasures) which entails that existence has no advantage over, but does have disadvantages relative to, nonexistence" (Benatar, Better, 30). 
result is that it is always better not to exist. ${ }^{22}$ Benatar's import is almost incredible: humans should cease to procreate as soon as possible, thereby engendering the extinction of the species - a view known as "anti-natalism." 23

\section{Ecclesiastes 6:3 in the Context of 5:9-6:9: “A Stillborn is Better Off'}

\section{A. Ecclesiastes 6:1-6}

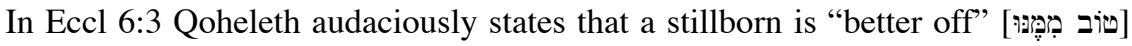
than a man he has just described. This man comes as the second of two examples with virtually identical structure, which either refer to the same man, or are parallel enough that we may analyze them interchangeably and draw the same conclusions about both. ${ }^{24}$

\section{Introduction - 6: $\mathbf{1}^{25}$}

There is an evil [רָָָָ] that I have seen under the sun, and it weighs heavily upon humanity:
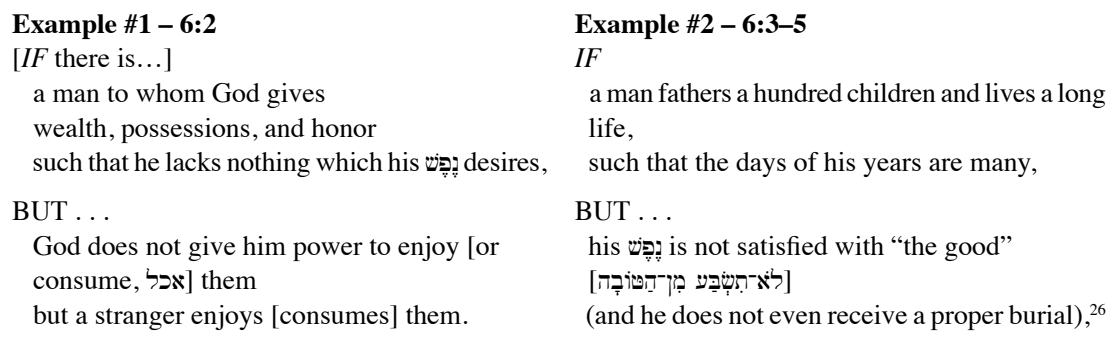

${ }^{22}$ For the full argument see Benatar, Better, chapter 2, 18-59.

${ }^{23}$ I should note that this is virtually an a priori argument, but not entirely one. All that Benatar needs to assume regarding the amount of pleasure and pain a hypothetical person will experience is the smallest imaginable amount of pain - such as, say, a single stubbed toe in an otherwise painfree, pleasure-filled life. As long as such a miniscule amount of pain may be assumed for all human lives, that is, as long as the amount is greater than "zero," his entire argument takes effect. This slightest bad outweighs any amount of good because the goods do not count. Hence Benatar's $a$ priori argumentation has furnished him with the absolute predictive power needed for such a claim as that "coming into existence is always a serious harm."

${ }^{24}$ Roland E. Murphy, Ecclesiastes (WBC 23A; Dallas: Word, 1992) 53, suggests that vv. 3-6 "can be considered an extension or an intensification of vv. 1-2 in that the failure to enjoy one's possessions and to fulfill one's desires remains the problem."

25 The following represents my translation of 6:1-5, but formatted to highlight the structure. (Words in brackets are not part of the translation proper but help to exhibit the structure.) 
[VALUE JUDGMENT]:

This is דֶֶ and a sickening evil.
[VALUE JUDGMENT]:

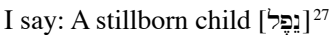

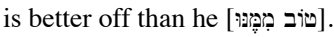

FOR

THOUGH

it comes in הֶֶֶ,

and goes in darkness,

and though it has not seen the sun nor known

anything, ${ }^{28}$

YET

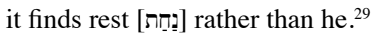

In the first case, the man has been divinely bestowed with riches, wealth, honor-seemingly all he could ever want-yet he lacks the ability to enjoy (literally

${ }^{26}$ I take this clause as parenthetical, with the wound for a joyless life, but it is not central to Qoheleth's concerns here.

${ }^{27}$ Apart from 6:3, נֶֶֶ occurs only twice in the Hebrew Bible: "Let them be like . . . a stillborn

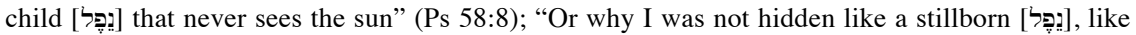
infants who have never seen the light?" (Job 3:16). Strikingly, all three instances identify the stillborn as one who "never sees the sun" or light, apparently reflecting an ancient Jewish circumlocution for consciousness as such.

${ }^{28}$ The Hebrew posits no object for ליא יָדי. This is unusual but not without precedent. C. L. Seow, Ecclesiastes (AB 18C; New York: Doubleday, 1997) 213, cites intransitive use of ידע in Isa $44: 9,18 ; 45: 20$. In all three cases the verb is negated, and in the former two texts the idols' lack of knowing is paralleled by a lack of seeing [ראה]. The import is that idols possess no cognitive faculty as such, and Qoheleth uses similar language to render the same point concerning the stillborn.

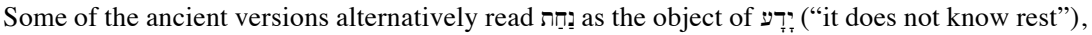
but the sentence's remaining syntax is then "exceedingly awkward" (Seow, 213). Moreover, the affinity of our text with Job 3:11-26 runs deep, and Job's repeated claim in the passage is that had he died as a "stillborn" [ניקֶּ] he would have been at rest [נוחל 3:13, 17, 26]. Job and Qoheleth agree that all that the stillborn does know is "rest."

${ }^{29}$ The string of descriptives by which Qoheleth characterizes the stillborn in 6:4-5 should be regarded as concessive with respect to the final clause ("Although . . . yet ..." as in the translation provided above). So JPS; Robert Gordis, Koheleth, the Man and His World: A Study of Ecclesiastes (New York: Schocken, 1968) 170; R. B. Y. Scott, Proverbs, Ecclesiastes (Garden City, NY: Doubleday, 1965) 231; Murphy, Ecclesiastes, 45. Others begin the concessive at v. 5: NIV; NKJV; ISV; James L. Crenshaw, Ecclesiastes: A Commentary (OTL; Philadelphia: Westminster, 1987) 120; Seow, Ecclesiastes, 202; Mette Bundvad, Time in the Book of Ecclesiastes (Oxford: Oxford University Press, 2015) 124. The concessive sense is not derived from any explicit Hebrew terms. Rather it is inferred by Qoheleth's implicit logic in the relationship between the value-states predicated of the stillborn. Verse 3 claims that the stillborn is better off than the man, and the ("for") at the beginning of v. 4 promises to provide justification for the claim. Yet none of the verbal clauses in v. 4 or the first half of v. 5 suffice, since none represents a positive value. Only the concluding statement in v. $5 b$ that there is "rest for this one rather than that one" (lit. Hebr.; see also 3:19, ז . . . כִ with fulfills the justificatory role of to v. $3 \mathrm{~b}$, and this relation is all the

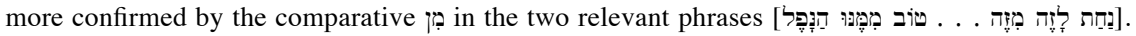
This linkage, in tandem with the negative value accorded to the stillborn's non-activities in vv. 4-5a, logically implies that the intervening clauses in vv. 4-5a (before the line about rest in v. $5 \mathrm{~b}$ ) function as a setup for the conclusion, conceding plenty about the stillborn's state as undesirable, but maintaining at least one decisive point over against the tragic man of 6:3. The stillborn is better 
"consume" or "eat" [אכל]]) these goods. ${ }^{30}$ In the second case, the man is said to have fathered a hundred children and lived an extraordinarily long life - the very ancient Near Eastern model of "the good life" - but nevertheless the man's his desire or appetite, is not satisfied with such good things. ${ }^{31}$ The crucial point is that in both cases the man is in possession of external, objective goods yet lacks a certain kind of internal, subjective response-namely, a positive, joyful one. Qoheleth's conclusion that the "stillborn child is better off" most directly refers to the second example, but again, given the strict parallelism it can almost certainly be applied to both cases. ${ }^{32}$

It is not difficult to see that the man constitutes a specific, contingent case. This fact alone distances Qoheleth's claim from Benatar's to some degree, since the stillborn is only said to be "better" than a man whose life meets these conditions. But, again, what is debated is whether this particular case nonetheless functions paradigmatically and definitively for Qoheleth. Inasmuch as this man's experience is meant broadly to represent the human condition-as is the case with so many of Qoheleth's vignettes - the sage would be claiming that non-existence is, if not always, at least generally preferable to human existence. There are scholars who think this is precisely the nature of Qoheleth's claim. Tremper Longman, for instance, writes that for Qoheleth, "Even if one should attain wealth, its enjoyment is rare .. . Only in those few cases where God gives not only wealth but also the ability to enjoy is the person buffered from the harsh pain of real life." ${ }^{33}$ James

off than the man, because-despite its own obvious deficiencies-it has more rest than the man. So Martin Rose, Rien de nouveau: Nouvelles approches du livre de Qoheleth (Fribourg: Vandenhoeck \& Ruprecht, 1999): "Le premier terme positif est נֵַ («repos», v. 5b). C'est lui qui doit expliquer pourquoi donner la préférence à l'état d'un fœtus inapte à vivre (v. 3b)." Moreover, the structure of Qoheleth's sentence about the stillborn (6:4-5) approximately parallels his sentence about the man (6:3). In the case of the man, a long list of positive traits is provided, only to undermine their value with a single phrase at the sentence's conclusion ("a stillborn is better off"). In the case of the stillborn, a long list of negative traits is given, only to subvert their disvalue at the sentence's surprising positive conclusion ("it finds rest rather than he").

${ }^{30}$ Robert Salters ("Notes on the Interpretation of Qoh 6:2," ZAW 91 [1979] 282-89) assumes that אכל must be taken literally. But this is an uncommon view. Most scholars think it can sometimes mean to "consume" in a broader sense, to "enjoy." See, e.g., George A. Barton, A Critical and Exegetical Commentary on the Book of Ecclesiastes (New York: Scribner, 1908) 129; Robert Alter, The Wisdom Books: Job, Proverbs, and Ecclesiastes (New York: Norton, 2010) 366: "The usage is an anticipation of a common idiom in rabbinic Hebrew, in which the verb 'eat' ('akhal) means to enjoy the fruits of something."

${ }^{31}$ For clarity's sake, I have omitted v. 6 from the translation above, but it too reiterates the requisite of subjective enjoyment: "Even if he should live a thousand years twice over yet not enjoy good [וְטוֹבָה לא רָָָה]-do not all go to the same place?"

32 The statement in 6:2 that "he lacks nothing which his ?ֶֶֶ desires" can only mean that the man has possession of all the objective goods which he would desire on the presumption that they will bring him subjective satisfaction; given what follows Qoheleth clearly cannot mean by this that the man has no subjective lack.

${ }^{33}$ Tremper Longman III, The Book of Ecclesiastes (Grand Rapids: Eerdmans, 1997) 175 [italics

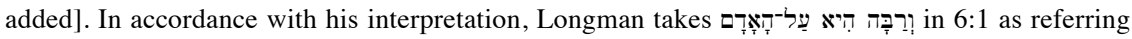


Crenshaw likewise posits that "Qoheleth's hatred of life was no momentary phase but persisted to the end, notwithstanding the seven texts that soften the pessimism for the lucky. For everyone else, God's favor did not abound." ${ }^{34}$ William Anderson, as well, suggests that 6:2 undermines the joy statement at the end of chapter five, turning the possibility of joy into a sick joke. ${ }^{35}$ However, there are several factors which, when taken together, challenge such an interpretation and urge us to regard the man's case as important and constitutive within Qoheleth's system of values, but nonetheless exceptional rather than universal. The argument will require some development.

\section{B. Ecclesiastes 6:2-3 as Exceptional Rather Than Universal}

To begin with, Qoheleth's description of the man in 6:2 is closely connected to his earlier description of "the good life" in 5:17-19. In fact, 6:2 almost exactly recapitulates an eleven-word Hebrew phrase from 5:18:

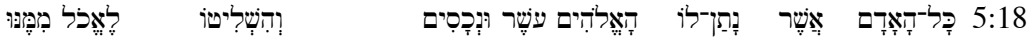

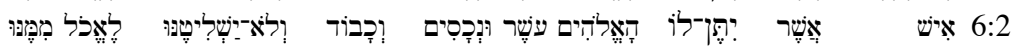

5:18 everyone to whom God has given wealth and possessions

6:2 a man to whom God gives wealth and possessions and honor

and the ability to enjoy it

but does not give the ability to enjoy it

The only two differences (besides the addition of "and honor" in 6:2) lie in (a) the subjects involved ("everyone to whom" versus "a man to whom"), and (b) the ל-negation in the last clause of 6:2. Regarding the first, identifying the subject as

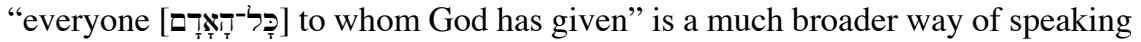

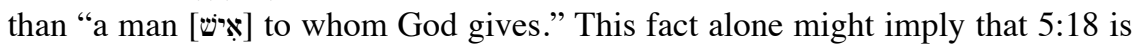
the more universal of the two. ${ }^{36}$ Regarding the second difference, the לא-negation in the second clause of $6: 2$ produces a pronounced contrast with $5: 18$. That Qoheleth would negate not the granting of possessions but specifically the ability

to the frequency of this רֶָ- "and it is frequent among humans" $(163,169)$. But the grammatical construction makes that unlikely, and the vast majority of commentators and translations construe it with reference to existential significance-"and it lies heavily upon humankind." See also 8:6,

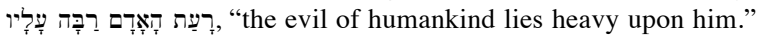

${ }^{34}$ James L. Crenshaw, "Qoheleth's Hatred of Life: A Passing Phase or an Enduring Sentiment?" in Wisdom for Life (BZAW 415; ed. Nuria Calduch-Benages; Berlin: de Gruyter, 2014) 119-31, at 128 [italics added]. Elsewhere Crenshaw opines that for Qoheleth "suicide offers a compelling alternative to further living. Its lure would seem irresistible for one who hates life and falls into despair's vice-like grip." Idem, "The Shadow of Death in Qoheleth," in Israelite Wisdom (ed. J. G. Gammie; Missoula, MT: Scholars Press, 1978) 208.

${ }^{35}$ William H. U. Anderson, Scepticism and Ironic Correlations in the Joy Statements of Qoheleth? (Piscataway, NJ: Gorgias, 2010) 54.

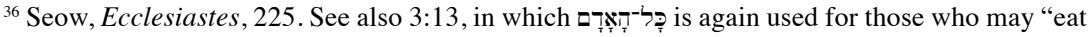
and drink and see good in their toil." In this case too, their ability to do so is grounded in "the gift of God," yet the emphasis is by no means exclusive, but inclusive and invitational. 
to enjoy them demonstrates that that is indeed Qoheleth's focus here-subjective appropriation, not objective possession. Mere possession of goods by no means guarantees their enjoyment, yet both are necessary for a truly good life. This differs from interpretations which hold that the "stranger" who is said to enjoy the man's goods in his stead has actually dispossessed the man of them. ${ }^{37}$ To be sure, that is a concern of Qoheleth's earlier in the book (2:18-23), but it is decidedly not the point in 6:2. Here in 6:2 the stranger [אִיש נָּבְרי] - which in this context most likely refers only to "someone else" 38 - is enjoying the goods still possessed by the man. ${ }^{39}$

The issue, then, is this: the goods are at hand, but this man cannot partake [אכל ] man's inability to enjoy renders his life inferior to the non-existent stillborn's. ${ }^{40}$ Most commentators here throw up their hands and offer something along the lines of Seow: "We do not know what kind of person Qohelet has in mind, or what circumstances may cause one not to enjoy material possessions. One can only guess whether the author is thinking of economic, physical, ${ }^{41}$ or psychological handicaps. ${ }^{42}$ Other scholars lay heavy emphasis on Qoheleth's reference to divine causality, that

${ }^{37}$ See, e.g., James Kugel, "Qohelet and Money," CBQ 51 (1989) 32-49; Michael V. Fox, A Time to Tear Down and a Time to Build Up: A Rereading of Ecclesiastes (Grand Rapids: Eerdmans, 1999) 130; William P. Brown, Ecclesiastes (Louisville, KY: John Knox, 2000) 64-65; Gordis, Koheleth, 257; Ludger Schwienhorst-Schönberger, Kohelet (Freiburg im Breisgau: Herder, 2004) 352.

${ }^{38}$ Stuart Weeks, Ecclesiastes and Scepticism (LHBOTS 541; New York: T\&T Clark, 2012) 80 n. 3; Graham S. Ogden, Qoheleth (Sheffield: JSOT Press, 1987) 91; Crenshaw, Ecclesiastes, 126.

${ }^{39}$ It is understandable that some commentators would connect the man's lack of enjoyment here with the possibility that God has dispossessed him of his property because in 2:18-23 the "despair" (and implicit lack of enjoyment) is due to the dispossession of wealth that is both inherited and thereby "enjoyed" by one "who did not toil for it" (v. 21). A further connection (between 6:2 and ch. 2) is proposed by those (such as Fox, Rereading, 129) who relate 2:26 to 2:18-23, since it could suggest the additional idea that the toiler's loss and the would-be fool's gain in 2:18-23 was in reality a divine prerogative. In light of the divine-causality rhetoric in 6:2, might not the same idea apply here and thus the man's inability to enjoy be provoked by a (divinely instigated) dispossession of property? But against this, the already discussed parallel between 5:18 and 6:2 strongly implies that in 6:1-6 Qoheleth is concerned to clarify a point he fears remains yet opaque-the absolute necessity of subjective enjoyment-and the point is best made via an example of a man who maintains possession of his wealth. In this way the lack of objective goods cannot be the source of blame. The joy Qoheleth commends in 5:17-19 could be misconstrued by his audience as a merely natural consequence of possessing "wealth and possessions" and similar external goods. But the emphasis in 6:2 - that the external, objective goods could be had without an internal, subjective appreciation for them - rules out any necessary correlation between the two aspects. Qoheleth could not have made that particular point if the dispossession of wealth were in view, for then the lack of enjoyment would be imputed to the external void.

${ }^{40}$ On the assumption already stated, that 6:2 and 6:3 either refer to the same man or are parallel enough to treat together, such that the stillborn "better" saying applies equally to the man of 6:2.

${ }^{41}$ Kurt Galling, "Der Prediger," in Die fünf Megilloth (HAT 18; Tübingen: Mohr Siebeck, 1969) 73-125, at 103, posits that "Krankheit verhindert das Genießen."

${ }^{42}$ Seow, Ecclesiastes, 225; see also Crenshaw, Ecclesiastes, 126; Murphy, Ecclesiastes, 53. For these scholars what is at least ruled out as the cause is dispossession. The handicap is something that coincides with the man's maintaining his goods, though its precise nature remains unclear. 
the man's absent joy is a gift withheld by God: "[Qoheleth] directly and solely attributes this negative state of affairs to God." ${ }^{43}$ To be sure, God's immanence in this text is unavoidable, yet does the appeal to divine causality exhaust all other explanations? In fact, Qoheleth elsewhere presents a concurrentist viewpoint, quickly appealing to divine causality as though it were the last word, only to offer a more "human" explanation for the same phenomenon within the turn of a few words $(\operatorname{Eccl} 7: 13,29) .{ }^{44}$

So why can't the man enjoy? I would like to suggest that the answer has been, so to speak, right under our noses all along. For Qoheleth states in 6:5 that the stillborn achieves "rest" rather than the man. ${ }^{45}$ The man's problem, then-his inability to enjoy "the good" [הָטוֹרָה] and its resultant inferiority for his existence at large - apparently owes itself to some kind of unrest. But precisely what sort?

Our text is embedded within the larger unit of 5:9-6:9.6 The primary theme of this unit is undoubtedly that of unfulfilled desire. Qoheleth begins the unit with the

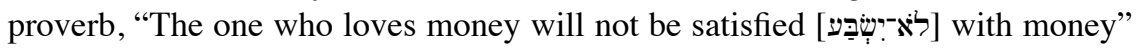
(5:9). And he concludes the unit in like fashion: "All of a person's toil is for his

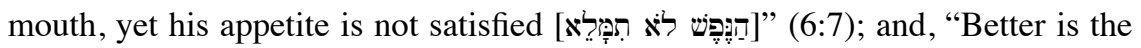
sight of the eyes [i.e. immediate enjoyment] than the wandering of desire נֶ: [i.e. unrelenting, insatiable desire]" (6:9). ${ }^{47}$ Between the inclusio containing three proverbs on each end $(5: 9-11 ; 6: 7-9)$ lie three sub-units $-5: 12-16,5: 17-19$, and 6:1-6.8 The first tells of a man who had toiled to accrue and then guard his

${ }^{43}$ Longman, Ecclesiastes, 170; see also Antoon Schoors, Ecclesiastes (Leuven: Peeters, 2013) 462. Stuart Weeks also emphasizes God's role in dispensing or withholding the ability to enjoy goods, but he minimizes the apparent arbitrariness of the act by tying it to divine judgment: "it is something offered in return for righteousness, or at least for pleasing God, while the withholding of the ability would constitute an effective punishment" (Ecclesiastes, 84).

${ }^{44}$ See, e.g., Psalm 7, which initially warns of seemingly unmediated divine punishment, "If a person does not repent, God will sharpen his sword" (v. 12), but quickly thereafter clarifies the more mundane means: "[a person] digs a pit and then falls into the hole he has made" (v. 15). See Yairah Amit, "The Dual Causality Principle and Its Effects on Biblical Literature," VT 37 (1987) 385-400.

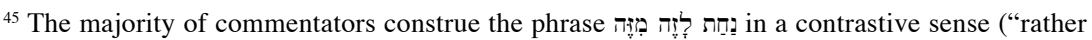
than"), although there are some who take the phrase in a comparative sense ("more than").

${ }^{46}$ For simplicity's sake in this paper I will only refer to the Hebrew versification, which in all of Eccl 5 reflects a verse number one less than that of English translations. E.g., HB 5:9= ET 5:10.

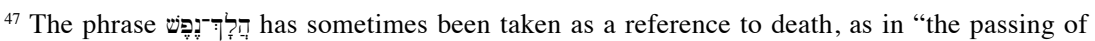
life" (Seow, Ecclesiastes, 228). This is unlikely for a number of reasons. First, כֶקֶׁ only refers to "desire" or "appetite" in Qoheleth, not "life." Second, translated as "the wandering of desire" the verse could not be better suited to its context, bringing the unit of 5:9-6:9 to a fitting conclusion. The two halves of the verse correlate perfectly with the two sections, 5:12-16 (the constant, lustful roaming of desire) and 5:17-19 (the ability to "see" as "good" that which is present).

${ }^{48}$ A few highly chiastic structures have been proposed for 5:9-6:9 (see Daniel C. Fredericks, "Chiasm and Parallel Structure in Qoheleth 5:9-6:9," JBL 108 [1989] 17-35; Seow, Ecclesiastes, 216-18). It is reasonable to see some resonance within the sections (e.g., the parallel between the "birth" language of 5:14 and 6:3), but the level of chiastic parallel assumed by these scholars is unpersuasive. My take on the structure of this section is only broadly chiastic, with a proverbial framing and the middle three sub-units reflecting a chiasm in basic theme ("evil" versus "good") 
riches, hoping to pass them on to his son as an inheritance, yet they were lost in a bad investment (5:12-13). Despite his toil [עמד in 5:14 5:15], the man will depart to the grave as naked as he came from the womb, ${ }^{49}$ having never achieved lasting "gain" ית:ירוֹן] (5:14-15). Moreover, we are told that the man spends his days in "darkness and much vexation [ذַַַِ], sickness and anger" (5:16). In other words, we might say that the man's compulsive teleological desire and his struggle to achieve it - his always wanting more, or his obsession to maintain what he has - is indeed a form of (what I will call) psychological unrest. ${ }^{50}$ In fact, the language here is highly reminiscent of chapter two, where Qoheleth reflects on the morose state

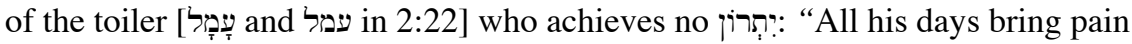

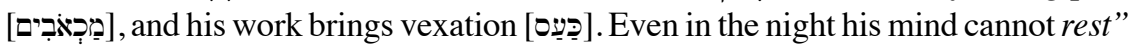

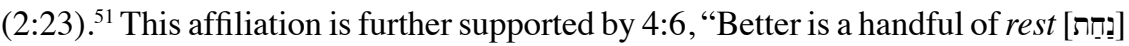

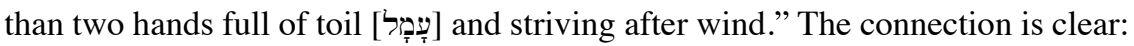
the toiler's compulsive teleological desire surfaces as psychological unrest - and unchecked psychological unrest incites the suffocation of joy. ${ }^{52}$

It is crucial to emphasize that Qoheleth is not only claiming that those enslaved by delusional teleological desire and the toil undertaken to that end fail to satisfy those (long-term) desires. He is also claiming that their future-obsessed psychosis can sometimes produce an unshakeable mindset that backfires onto the present, incapacitating them from even enjoying the best of what life does offer-eating,

while still maintaining progressive movement in the content of the argument (see below).

A - 3 Proverbs on Insatiable Desire (5:9-11)

$$
\begin{aligned}
& \text { B - "There is an Evil [יפש רָָּה]" (5:12-16) } \\
& \text { C - "What is Good [ט] [ن]" (5:17-19) }
\end{aligned}
$$

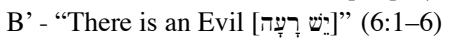

A' - 3 Proverbs on Insatiable Desire (6:7-9)

49 The phrase "Just as he came from his mother's womb, naked he will return, just as he came"

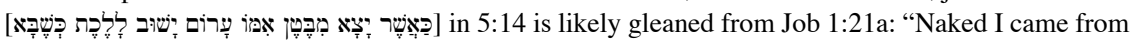

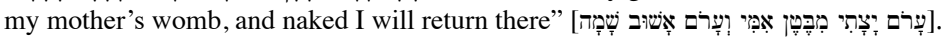

50 The man's psychological problems are not meant merely as a result of his misfortune, but as concomitant with it. The same is true with $2: 23$ in relation to $2: 18-22$. See also $1: 18$, where

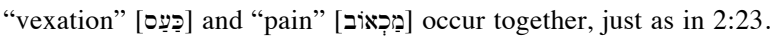

${ }^{51}$ This interpretation particularly illuminates certain other passages in Qoheleth:

a) 11:9-10: Qoheleth's exhortation at the end of chapter 11 is to "walk in . . the sight of your eyes," i.e. immediate enjoyment (11:9; compare 6:9), and to "remove vexation [ַِِ] from your mind" (11:10). He is again commending the embracement of present joys as a way out of the psychological unrest ("vexation") that plagues those enslaved by toil and teleological desire.

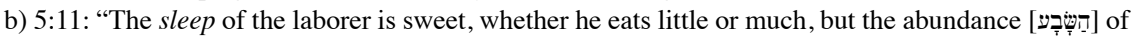

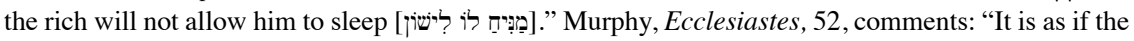
riches that the eyes contemplated so avidly now keep them from being closed in sleep."

${ }^{52}$ Schopenhauer similarly conceives of existence as "essentially unceasing motion, without any possibility of that repose which we continually strive after . . Existence is typified by unrest" (Schopenhauer, Essays and Aphorisms, 52 [italics omitted]). See also Euripides, Hipp. 189-190 [Kovaks, LCL]: "But the life of mortals is wholly trouble, and there is no rest from toil." 
drinking, enjoying one's toil-impermanent benefits, but valuable nonetheless ${ }^{53}$ In such a state, with the mind restlessly fixated only on what is beyond the horizon, a person is utterly incapable of enjoying present goods - the sort proposed in 5:17-18 but denied the man in 6:2-3. This, I propose, accounts for the man's inability to enjoy his good possessions in 6:2. And it is this backfiring effect of insatiable teleological desire which, according to Qoheleth, can render a life worse off than non-being..$^{54}$

But to return to our question: Who can enjoy such goods? Only a few? In light of our proposed rationale for the man's inability to enjoy good in $6: 2$, we can see the way the unit's structure-specifically the relation between the three sub-units 5:12-16, 5:17-19 and 6:1-6-argues for reading 6:1-6 as exceptional.

The distressed toiler of 5:12-16 may well represent a broad swath of humanity for Qoheleth, not in terms of the man's precise circumstances as much as the story's broader application: every human will eventually return to the grave "naked" and no one's toil will result in permanent gain. It is all "toiling for the wind" (5:15). Given this theme's prominence in the book, Qoheleth at least seems to think that in some form or another unfulfilled teleological desire is epidemic among humanity. That is precisely why Qoheleth's next move (and one made throughout the book) is to provide a remedy for this all-too-common malady: to turn one's eye from whatever telos is believed to fill the insatiable hunger of the ?ֶֶ, and instead turn to "see good" in the simple pleasures of the present (5:17-19). Qoheleth's clarion calls to joy throughout the book carry exhortative force. ${ }^{55}$ His assumption is therefore that in principle anyone can do this-again, the rhetoric of divine causality notwithstanding. Anyone can heed his words and turn from a slavery to teleological desire toward the free embracement of present goods, the only "portion" [חקל ] God has provided.$^{56}$ Even in the face of life's inevitable הָבְ מִלים, anyone can choose a life

${ }^{53}$ For instance, the toiler in 5:16 is not even able to enjoy "eating," though the next verse designates the same activity as "good." The toiler in 4:8 represents another instance of this principle in the book. His toil is driven by an insatiable desire ("There is no end to all his toil, and his eyes are not satisfied with riches"), and his self-critical question reflects the presupposition that the toiler's future-oriented desire prevents him from present enjoyment: "For whom am I toiling and [thereby]

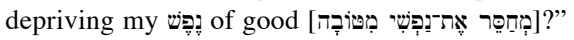

${ }^{54}$ It should be noted that Qoheleth's critique of teleological striving throughout the book seems to indicate a reversal from a viewpoint he formerly held. Much like Tolstoy's famous recounting of his mid-life existential crisis (Leo Tolstoy, Confession [trans. David Patterson; New York: Norton, 1983]), Qoheleth often writes as though he has experienced an epiphany (employing the language of, "I saw," "I realized," etc.) which has overturned previous expectations and beliefs. This implies that Qoheleth writes as a recovering teleologist. He still believes that teleological striving would be the best way to live if the objects of one's teleological desires were real and attainable. But since he no longer believes humans can grasp such objects, he wants to prevent the harm caused by needlessly chasing illusions. If the teloi are forever out of reach, then there is "nothing better" than taking hold of graspable present-tense goods.

${ }^{55}$ Qoheleth's joy commendations begin with his definitive statements of what "is good" for a person to do $(2: 24 ; 3: 12-13,22 ; 5: 17-18)$ but are eventually expressed as explicit injunctions to the reader in the imperative mood $(7: 14 ; 8: 15 ; 9: 7-10 ; 11: 8-10)$.

${ }^{56}$ Commensurate with this interpretation is that among the book's many joy-exhortations only 
which, at the very least, is worth living and is better than non-existence. ${ }^{57}$ All that is required is a change in mindset.

In a few unique circumstances, however, the "demon is in too deep." Herein lies the "sickening evil" (דָזי? רָע) 6:2-3. Some, such as the man portrayed in these verses, have become so entrenched within their teleological desire that they are incapable of curbing those desires for something more within reach. If the movement from 5:12-16 to 5:17-19 represents the shift between a description of the malady and a prescription for the remedy, we might say that the final move to 6:1-6 represents a description of those for whom this cure is sadly ineffective. Only with respect to these, the tragically incurable, is Qoheleth obliged to admit that the stillborn's serene, painless state is "better": while neither enjoys life's goods, the stillborn at least finds (psychological) "rest." The movement between these sections therefore exhibits a progressive narrowing within Qoheleth's field of vision. In light of this, the man of 6:2-3 represents not the rule, but an exception.

\section{Ecclesiastes 4:3 in the Context of 4:1-3: "Better is the One Who Has Not Yet Been"}

In Ecclesiastes 4:2-3, Qoheleth follows a description of a community suffering oppression (4:1) with two statements praising the state of non-existent persons: "And I praised the dead who are already dead more than the living who are still

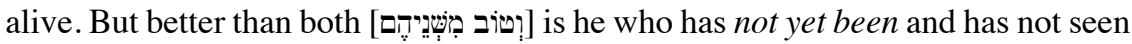
the evil deeds that are perpetrated under the sun" (4:2-3). Some scholars have been hesitant to take Qoheleth seriously here. Barton suggests this was "not [Qoheleth's] settled opinion. It was rather a transitory mood." ${ }^{58}$ On the other hand, pessimistically inclined interpretations of the book see verses like these as quintessential to the sage's thought: "This preference for the nonexistent over the dead or the living suits the hatred for life that Qohelet expressed in 2:17," writes James Crenshaw. ${ }^{59}$ Likewise, W. Sibley Towner: "Nonexistence is preferable to existence, though the Teacher does not advocate suicide." ${ }^{60}$ It is true that these statements have more of

in 5:18 are "wealth," "riches," or "possessions" identified as the objects of joy; elsewhere the objects in view are almost exclusively the more democratized objects of one's eating, drinking, and labor. Even in 5:18 the accoutrements of the wealthy are distinguished from the previous verse by the ("also"), perhaps implying that this exhortation belongs to a slightly different category, one more difficult to accomplish-hence 6:2. Qoheleth's point is that the basic enjoyment of life through mundane means is something anyone-rich or poor-can do, and the poor may even be more equipped for the task since they are not weighed down by the "vexations" of the rich (5:9-11).

${ }^{57}$ For Qoheleth, life's present worthwhileness is grounded not in the sort of "meaning" which an attainable and irrevocable יתרוֹן ("gain," "profit") would have produced (if that were possible). It stems from a more basic kind of value: the subjective enjoyment of objective goods-even if both are transient.

${ }^{58}$ Barton, Ecclesiastes, 114.

${ }^{59}$ Crenshaw, Ecclesiastes, 107.

${ }^{60}$ W. Sibley Towner, "The Book of Ecclesiastes," in The New Interpreter's Bible (ed. Leander E. Keck; 12 vols.; Nashville: Abingdon, 1998) 5:267-360, at 311. 
a universal ring to them than the "stillborn" saying in 6:3. But, once again, there are good reasons to think Qoheleth has something more particular in mind.

First, the verb ראה, one of Qoheleth's favorites, is used here with reference to "seeing the evil deeds that are perpetrated under the sun." Taken in its literal sense, Qoheleth would be suggesting that merely witnessing evil or oppressive acts renders one inferior to the non-existent. In that case, presumably a large percentage of humanity would be negatively construed. But Qoheleth is quite apt to use ראה in another sense - that of immediate experience. Apart from his own first-person uses (e.g., "I have seen"), this is actually the sense that predominates throughout the book - utilized roughly twelve times ${ }^{61}$ Even in the text from chapter six discussed earlier, Qoheleth refers to enjoyment with the Hebrew phrase literally rendered, "see good" (טוֹבָה . . . רזָָה, 6:6). ${ }^{62}$ In such cases itself refers only to a valueneutral experience; it is the verb's object —in this case the טنרז -which justifies an idiomatic translation of "enjoy." So too, here in 4:3, "seeing the evil deeds" [רָה "An " [צֶת may legitimately be glossed as "suffering from oppression." Applied to in 4:3, Qoheleth would not be asserting that the non-existent are better off than all those who have witnessed oppression - again, this would presumably condemn most of humanity - but only better off than those who have not directly experienced such oppression as is described in v. 1 .

But there is more to this negative experience than its external harms. In v. 1, Qoheleth not only grieves the oppression undergone at the hands of those who abuse power, but with a kind of mournful repetition he twice bemoans the additional fact that "there is none to comfort them." As in chapter six, our sage is concerned not only with the objective situation in which humans find themselves, but their subjective response to it. It is precisely the subjective-appropriative side of things the compensatory feeling of comfort-which the presence of comforters would engender for those undergoing oppression. Yet this is denied them. The implication is that an irredeemable evil plagues this community; they experience only harm and no good. As such, Qoheleth affirms that it would indeed be better for them not only to have died, but not to exist.

Second, and related to this last point, Qoheleth's exact wording of the phrase in

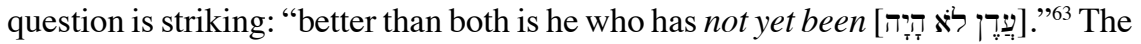
sage is considering the lot of a hypothetical, non-existent person, but he does not articulate this as, for instance, "one who never will be." He describes the person as in a state of "not yet" existing (as well as not yet "seeing the evil deeds"), implying that this one may well come into existence at some future point. ${ }^{64}$ If so, he is likely

${ }^{61}$ Eccl 1:16; 2:1, 3(?), 16; 3:13; 4:3; 5:18; 6:6, 9; 7:11(?); 9:9; 11:9.

${ }^{62}$ The "see good" idiom is employed in Eccl 2:1, 3, 24; 3:13; 5:17; 6:6 (see also 9:9, "see life," typically translated "enjoy").

${ }^{63}$ Gordis, Koheleth, 239, notes that "the common Mishnaic עדיין, 'yet', suggests rather that our spelling here is the old orthography for the ai diphthong in which the Yod was unexpressed."

${ }^{64}$ Longman, Ecclesiastes, 135. 
thinking of (not just any person but) one born into the oppressed community. Such a person is in a better state for as long as they remain non-existent; for upon entering the community's woeful state, things will quickly become bleak. ${ }^{65}$

It would appear, then, that, in contrast to David Benatar, neither of Qoheleth's aforementioned "better" statements $(6: 3 ; 4: 3)$ constitutes a definitive claim by the sage that non-existence would be universally better for all people, or even the vast majority of humans. Qoheleth does indeed think that some people's lives - whether through an utter inability to experience the good things in life, or through a situation of irredeemable evil in which both objective and subjective goods are lacking - do indeed fail to produce value. But these are exceptions; they are not the norm. ${ }^{66}$

\section{Dialogue with David Benatar}

Thus far, we have done little to justify this paper's subtitle concerning a dialogue between David Benatar and Qoheleth. I have mainly used Benatar's thesis as an opportunity for Qoheleth to respond (via my pen) to the challenge it poses and to clarify the rationale for Qoheleth's view, which we have found to differ from Benatar's thesis in its main conclusions. But I would like now to fill the lacuna by offering some semblance of dialogue.

First, what do the two philosophers have in common? Qoheleth shares Benatar's intuition that there is something rather enviable about non-existent persons: they bask in an utterly peaceful, painless nothingness, finding the perfect "rest" to which so many of we existers ever fruitlessly aspire. ${ }^{67}$ One step further, Qoheleth agrees that this blissful nothingness can, at times, outweigh the value of a life bereft of both long-term goal-satisfaction and short-term happiness. Remarkably, both Qoheleth and Benatar are at least sometimes comfortable predicating "betterness" to a hypothetical person in a non-existent state.

But, secondly, where do the two part ways? It has already become apparent that their conclusions ultimately differ: despite the pessimistic tones of Eccl 4:3 and 6:3, Qoheleth would not agree with David Benatar that coming into existence is always, or even generally, a harm. But what exactly is the line of reasoning at play that leads to these divergent conclusions? Essentially, it is a difference of

\footnotetext{
${ }^{65}$ This interpretation is further supported by the parallel with 2 Bar. 10:6-7, 14-16 [Klijn, OTP]: "Blessed is he who was not born, or he who was born and died. But we, the living, woe to us, because we have seen those afflictions of Zion ... And those who have no children will be glad, and those who have children will be sad. For why do they bear in pains only to bury in grief? Or why should men have children again ... where this mother is lonely, and her children have been carried away in captivity?" The writer's pessimistic stance holds true with respect to the oppressed community, not all humanity in general.

${ }^{66}$ Seow, Ecclesiastes, 225, regards the balance similarly: "As a general rule, God has permitted humans to enjoy what they have, given them material possessions, and authorized them to partake of what they have as their portion. This is the manifestation of God's gift to humanity. Yet there are instances when that gift is not evident, when the same God who gives material possessions may not give certain individuals the ability to enjoy them."

${ }^{67}$ Clearly, I am "personifying" the non-existent somewhat to make the point.
} 
epistemological method. Whereas Benatar's “Asymmetry Argument” utilizes an a priori argument devoid of appeal to human experience, Qoheleth's method is more empirical - that is, it involves investigating and giving credence to the benefits and harms experienced by particular humans. ${ }^{68}$ Not until that empirical work has been done is Qoheleth willing to stake a claim that either existence or non-existence would be better in any given case. Universal judgments are thrown out of court entirely. ${ }^{6}$

One correlating aspect of this methodological difference lies in the two thinkers' respective assumptions about the possibility for a comparison between the goods of existence and the lack of such goods in non-existence: Benatar's disallowal of such a comparison coheres with his a priori method, while Qoheleth's openness to this comparison aligns with his empirical method. To unpack this distinction in greater detail, a brief review of Benatar's thesis on this point may be helpful. Benatar's proposal, we may recall, is that while the pains of existence do indeed compare unfavorably with the painlessness of non-existence, the pleasures of existence are (quite surprisingly) "not an advantage" over their absence in non-existence. Where we expect symmetry, Benatar pronounces asymmetry. By saying that the goods are "not an advantage," 70 Benatar is implicitly claiming that the goods of existence cannot genuinely be compared with their corresponding absence in nonexistence - thus, the two states are incommensurable. ${ }^{71}$ Harms can be compared, he maintains, but benefits cannot be. And if so, then life's goods can never be taken into account and the mere possibility that the goods will outweigh the harms in any individual's experience is ruled out. If only pains, and not pleasures, are weighed on the scales of value, then the scales will weigh in favor of non-existence every time. But what is distinct about life's goods, such that Benatar feels justified to

68 The most influential work on Qoheleth's epistemology remains Michael Fox, “Qohelet's Epistemology," which demonstrates that the sage exhibits "an essentially empirical methodology" (137).

${ }^{69}$ Qoheleth's method is therefore similar to the "intuitive" method we considered in the opening paragraph of this essay. But the difference is that Qoheleth is not considering human existence as a conglomerate and then declaring "better" or "worse" over it in toto; instead the value judgment is only assigned to particular people or groups of people, given their particular circumstances.

${ }^{70}$ Benatar, Better, 41: "The pleasures of the existent, although good, are not an advantage over non-existence, because the absence of pleasures is not bad. For the good to be an advantage over non-existence, it would have to have been the case that its absence were bad."

${ }^{71}$ Benatar does not explicitly claim incommensurability, but it is a logical implication of his notion that if the absence of X is "not bad," then the presence of X is not an "advantage" or better (see previous note). We might add parenthetically that if Benatar's conclusion seems confusing, it is because he appears to be equivocating on the term "bad" and conflating the categories of intrinsic bad (or harm) and comparative bad (or harm). As pointed out above in n. 20, the fact that some circumstance is "not bad" in itself (i.e., not intrinsically bad) never implies that some other circumstance could not be better - as Benatar here claims it cannot be. That which is worse off in a comparison suffers not intrinsic harm but comparative harm. The runner who finished in second place is in a "not bad" state, all things considered, yet she suffered the comparative harm of not finishing in first place. Correspondingly, the first-place finisher enjoys advantage or comparative benefit over the second-place finisher. 
rule them out? Once again, Benatar's foundational premise for this argument is that non-existers cannot be deprived - that is, according to his particular use of the term, they cannot be said to feel a subjective lack that they are "missing out" on some good thing existers experience, since if they never come into existence they will have no reason to "miss" anything. ${ }^{72}$ Would Qoheleth agree with this?

Qoheleth would in fact reject this premise, and as a result he would also deny Benatar's claim of incommensurability. We know this because when he speaks of non-existers he not only mentions their relative benefits - e.g., their perfect "rest" in place of insatiable desire (6:5), or their auspicious fortitude from oppression (4:3). But he also acknowledges their deprivations - they never "see the sun" שֶֶֶׁ" ללאץ-רָאה [לא ידָָע], never "know anything"; they traverse only "in darkness" rather than light (6:4-5). ${ }^{73}$ All of these things are explicitly mentioned elsewhere in the book as objective values, even comparative advantages or benefits, for the living, and thus to go without them is to be objectively deprived. In 11:7, Qoheleth begins his final exhortation, "Light is pleasant, and it is good for the eyes to see the sun

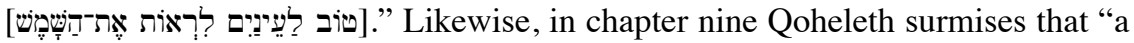
living dog is better off than [טוֹ מיב have knowledge and the experience of brute consciousness, unlike the shadowy

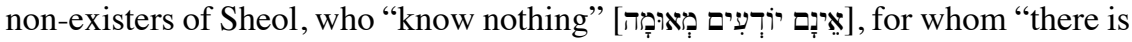
no work or thought or knowledge or wisdom" $(9: 5-6,10) .{ }^{74}$ People are better off for experiencing these things, and worse off for lacking them.

${ }^{72}$ Benatar, Better, 58. While it is not the purpose of this essay for me personally to critique David Benatar's philosophy (as much as to allow Qoheleth the opportunity), it is difficult not to notice a questionable element in his foundational premise, which then logically extends to his entire project. Benatar assumes that "deprivation" is only a subjective category involving the conscious awareness of that which is lacking: since non-existers have no consciousness of what they lack, they are not being "deprived" of life's goods. But in fact, it seems more typical to regard deprivation in an objective sense, and Merriam-Webster Dictionary defines "deprivation" in purely objective terms: "the state of being kept from possessing, enjoying, or using something: the state of being deprived" (Merriam-Webster Dictionary, "Deprivation," https://www.merriam-webster.com/dictionary/ deprivation). For example, the 2015 film Room portrays a boy who has spent the first five years of his life trapped inside a small, filthy room, playing with paper boats in toilet water. The boy experiences no subjective awareness (and thus feels no subjective deprivation) of the world beyond those walls - of grass, trees, animals. Yet, this in no way prevents us from surmising that the boy has been genuinely "deprived" of something which would have been good for him. The same would seem to apply for non-existent persons: they are missing something which would have been good for them to experience, whether or not they know it.

${ }^{73}$ As discussed in n. 29, Qoheleth lists the deprivations that can be predicated of the stillborn as concessive with respect to its sole advantage-rest.

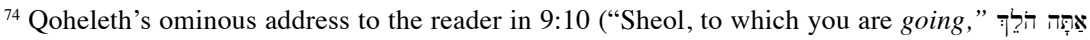

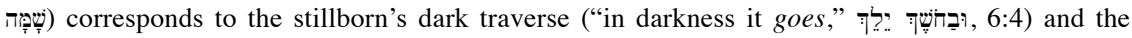

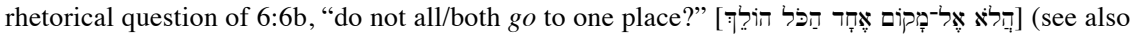
$3: 20 ; 5: 14-15 ; 12: 5)$. Even though the book's prologue characterizes "going" [הלד] in the world as a generally interminable affair (e.g., 1:4, 6, 7), death provides the exception to the rule. If any telos be granted for human "goings" in Qoheleth's philosophy, it is death alone. 
For Qoheleth, then, it is false that "those who never exist cannot be deprived." But this is not because Qoheleth thinks non-existent persons are somehow aware of life's goods and yearning to experience them. Rather, it is because Qoheleth, unlike Benatar, regards a "deprivation" as an objective lack of some good, whether or not a felt sense of lack enters one's subjective awareness. Since the objective possession of goods (in existence) and their lack (in non-existence) can be compared, Qoheleth can therefore posit a genuine value-comparison between existers and their non-existent counterparts with respect to both the relevant pains and-here in distinction from Benatar-pleasures. This by itself does not guarantee a worthwhile existence, but it does mean that existence and its goods may be weighed against non-existence on an unbiased, evenly balanced scale.

For the ancient sage, life's mundane pleasures (seeing the sun, having knowledge) are examples of intrinsic goods, and a person would be (comparatively) harmed by not enjoying them. ${ }^{75}$ Yet, as we have already seen, enjoy them they must - this part is not optional. In other words, what we have now seen is that Qoheleth's philosophy of life's value fully hinges on both the subjective enjoyment of the goods at hand as well as the objective, intrinsic worth attributed to those goods. The objective possession of goods (over against their utter lack in non-existence) meets a necessary condition or minimum requirement for positive value, but the subjective enjoyment of these goods meets the sufficient condition: both are required for the triumph of being over non-being.

This means that only in comparison to a life which is not enjoying these things anyway - a life for which these goods do not "count" - would non-existence be better. ${ }^{76}$ What the stillborn and the man in 6:2-3 share in common is an inability

${ }^{75}$ This account of harming is referred to in contemporary philosophical literature as the counterfactual comparative account (CCA). See Feinberg, "Wrongful Life"; Craig Purshouse, "A Defence of the Counterfactual Account of Harm," Bioethics 30 (2016) 251-59; Justin Klocksiem, "A Defense of the Counterfactual Comparative Account of Harm," American Philosophical Quarterly 49 (2012) 285-300. Klocksiem defines a harm as the following: "an event, $e$, constitutes a harm for $S$ if and only if $S$ is better off in the nearest possible world in which $e$ does not occur than she is in the relevant $e$-world" (285). I would only modify this account by clarifying that the event which constitutes the harm may also be a "non-event," or non-occurrence. This would be true in cases where a potential person (who, if conceived and born, would have lived an overall beneficial life) is harmed by not being brought into existence: a particular event which might have occurred does not occur, and this creates a harm. It must be acknowledged that this position does entail an apparently ludicrous implication - namely, that billions upon billions of potential but unconceived humans have been "harmed" by not being brought into existence, and thus deserve our grief (Shelly Kagan, Death [New Haven: Yale University Press, 2012] 221). But this implication need not be a defeater for CCA. It may well be the case that some untold number of potential, non-existent persons have been harmed in the comparative sense, but a comparative harm is (in most cases) not nearly as severe as an intrinsic harm (such as being inflicted with prolonged pain), and so the degree of grief we might feel for the billions of unconceived persons might be comparable to the degree of grief we feel that many of our own lives are not much greater than they actually are, certainly not as great as they theoretically could be if other events would have occurred (or not occurred). My interpretation of Qoheleth suggests he would concur with a CCA account.

${ }^{76}$ Note that both Benatar and Qoheleth arrive at the conclusion that non-existence is better only 
to enjoy good; but the stillborn's stated advantage is that it alone obtains "rest" which is to say, it evades the pain of unfulfilled teleological desire and its attendant psychological unrest.

\section{Conclusion}

One way to systematize certain claims of this paper is to see that the ancient sage has an implicit value ranking of hypothetical life scenarios. Non-existence is not at the top, as it is for our contemporary, the philosopher David Benatar. Pride of place belongs to an existence marked by fulfilled teleological desire-a person toils, constantly longs for more, grasps for permanence - and lo, they achieve it. They obtain satisfaction of those desires. Qoheleth can apparently imagine such a world, and it serves as the standard against which he evaluates the world he knows by experience. But it is purely hypothetical, an unattainable mirage. Moving on from the hypothetical to the real, next best would be an existence that is indeed marked by הֶבֶ and frustration, as life "under the sun" inevitably is, but nonetheless affords its own enjoyable goods. There is real value to living in such a world, even if it is less than ideal. Enjoyment of the goods at hand is the life which Qoheleth himself seeks and commends to his readers. However, if that sort of existence cannot be obtained, the next best option - third in Qoheleth's rankings - is that of non-existence. The painless serenity of non-existence would indeed out-benefit its next competitor, the life in which a positive reception of goods (or even a positive coping with evil, as in 4:3) is not possible.

We have seen, then, that despite initial appearances, Qoheleth does not regard coming into existence as a universal harm. To put it simply, it depends. Qoheleth is not a pessimistic nihilist, nor a naïve optimist, but actually a moderate, a realist. ${ }^{77}$ Yet such cases as Qoheleth has described in 4:3 and 6:2-3 are best seen as exceptions to the norm, and they can easily be avoided if one heeds the sage's exhortation to exchange the insatiable desire for what lies beyond in favor of a joyful contentment with what lies at hand.

in situations where no goods are tallied whatsoever. In other words, neither of them makes the claim based only on some amount of badness outweighing some lesser amount of goodness. The difference is that for Qoheleth, this non-contribution of goods is a unique condition, whereas for Benatar, it is a priori universal, given his "no deprivation for non-existers" premise.

${ }^{77}$ Kagan, Death, 258, explains the three categories as follows: (a) optimists are those who think that always and for everyone, existence is better than non-existence; (b) pessimists believe the opposite, that non-existence is always to be preferred; (c) moderates hold that it depends on the given circumstance. 
Qoheleth's Implicit Value Ranking of Scenarios

\begin{tabular}{|c|c|c|c|c|c|}
\hline Value \# & Terms & $\begin{array}{l}\text { Relative Goods / } \\
\text { Benefits }\end{array}$ & Relative Harms & $\begin{array}{l}\text { Ontological } \\
\text { status? }\end{array}$ & Possible? \\
\hline $\begin{array}{l}\text { Value \#1 } \\
(5: 12- \\
16)\end{array}$ & 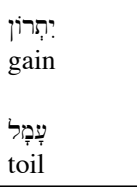 & 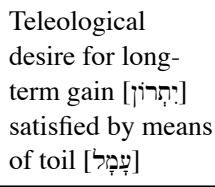 & (none) & Existent & $\begin{array}{l}\text { Impossible } \\
\text { Hypothetical }\end{array}$ \\
\hline $\begin{array}{l}\text { Value \#2 } \\
(5: 17- \\
19)\end{array}$ & 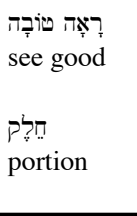 & $\begin{array}{l}\text { Rid of } \\
\text { (unsatisfiable) } \\
\text { teleological desire } \\
\text { Able to enjoy } \\
\text { present goods }\end{array}$ & $\begin{array}{l}\text { Ideal teleological } \\
\text { desires not satisfied }\end{array}$ & Existent & Possible \\
\hline $\begin{array}{l}\text { Value \#3 } \\
(6: 3 b-5)\end{array}$ & 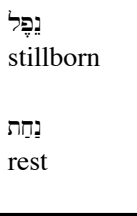 & $\begin{array}{l}\text { Achieves } \\
\text { "rest" - the lack } \\
\text { of unsatisfied } \\
\text { teleological desire } \\
\text { and psychological } \\
\text { unrest }\end{array}$ & $\begin{array}{l}\text { Unable to obtain } \\
\text { long-term gain [יתרון ] } \\
\text { Unable to enjoy } \\
\text { present goods }\end{array}$ & $\begin{array}{l}\text { Non- } \\
\text { existent }\end{array}$ & Possible \\
\hline $\begin{array}{l}\text { Value \#4 } \\
(6: 1-3)\end{array}$ & 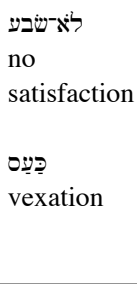 & (none) & $\begin{array}{l}\text { Teleological desire } \\
\text { for תִ: } \\
\text { unsatisfied but } \\
\text { unabandoned and } \\
\text { thus: } \\
\text { unable to enjoy the } \\
\text { good and unable to } \\
\text { "rest" }\end{array}$ & Existent & Possible \\
\hline
\end{tabular}

